Postdramatik:

\title{
Dramaturgi Teater Indonesia Kontemporer
}

\author{
Afrizal $\mathbf{H}^{1}$ \\ Program Studi Seni Teater, Institut Seni Indonesia Padangpanjang, Indonesia \\ Kurniasih Zaitun (Penulis Koresponden) \\ Program Studi Seni Teater, Institut Seni Indonesia Padangpanjang, Indonesia \\ Susandro \\ Program Studi Seni Teater, Institut Seni Budaya Indonesia Aceh, Indonesia
}

\begin{abstract}
Postdramatic: The Dramaturgy of Contemporary Indonesian Theater. The research attempts to explain a new possibility in theatre practice in Indonesia, which was initially formed through the power of words in the form of dialogue depicted in drama scripts. Since then, there was another tendency which was a matter of fact, in the early 1920s, for which Antonin Artaud initiated. Various terms have been used to describe new trends in the dramaturgy of Indonesian theatre since the 1970s up to now, such as cutting-edge theatre, avant-garde theatre, experimental theatre, body theatre, visual/visual theatre, postmodern theatre, contemporary theatre, and so on. Therefore, the appearing terms show doubts in determining the identity of the currently developing Indonesian theatre. This study aims to explain the potential for postdramatic theatre works that have been performed by Indonesian theatre directors, such as WS Rendra, Putu Wijaya, Boedi S. Otong, Dindon WS, Rahman Sabur, Yudi A Tajudin, including Yusril with a Postdramatic theatre approach. This research method is dominated by literature studies that take references such as books, journal-based articles, and online and printed media. The results of the study indicate that postdramatic dramaturgy in the practice of theatre in Indonesia is necessary from the spirit of the times that formed it, including the possibility of creating a new form of post-dramatic theatre developing in the current era of the Covid-19 pandemic.
\end{abstract}

Keywords: postdramatic; dramaturgy; theatre; Indonesia; contemporary

\section{Pendahuluan}

Istilah teater postdramatik belum begitu populer dalam praktik perteateran di Indonesia. Salah satu rujukan terkait diskursus mengenai teater postdramatik di Indonesia adalah diskusi yang dilaksanakan oleh Komite Teater Dewan Kesenian Jakarta (DKJ) di Galeri Cipta III Taman Ismail Marzuki (TIM) Jakarta pada tanggal 18 September 2016 dengan judul Ngobrol Teater Enter: Laboratorium Kampus \& Postdramatik². Dalam diskusi ini, wacana teater postdramatik digulirkan. Teater postdramatik merupakan dramaturgi baru dalam praktik penciptaan teater yang mencoba melakukan antitesa terhadap konvensi teater sebelumnya yang memposisikan teks drama sebagai basis utama di dalam proses penciptaan teater. Penciptaan teater dalam perspektif postdramatik, memberikan

\footnotetext{
$1 \quad$ Alamat korespondensi: Rumah Petak (Parabola MNC Vision), Jalan M. Syekh Jamil, No. 59, RT VI, Kel. Koto Panjang, Kec. Padangpanjang Timur, Kota Padangpanjang, Sumatera Barat, 27122. Email: afrizalharun@ gmail.com; HP.: 081363603004.

2 https://dkj.or.id/artikel/catatan-atas-diskusi-teater-postdramatik/, dilihat pada 27 Juli 2021.
} 
ruang demokratik dan heterogen di dalam melakukan eksplorasi, elaborasi terhadap ide atau gagasan teater yang dibuat.

Teori post-dramatik yang diungkapkan oleh Lehman adalah bukti dari empasis baru yang terjadi di wajah pertunjukan Eropa dan Amerika khususnya seni teater dimulai sejak dekade 1960-an, yang konsekuensinya adalah berubahnya paradigma dalam pembahasan ilmu teater dan memunculkan studi pertunjukan sebagai disiplin ilmu. Kemunculan bentuk pertunjukan seni neoavant-garde seperti happening, enviromental, fluxus event dan performance art atau bisa juga disebut live art semuanya menghasilkan perhatian baru dalam anggapan pentingnya performance di dalam cakupan teater dan ini memperbaharui tantangan dari dominasi teks, yakni tantangan yang sebelumnya pernah ditaklukan oleh seorang avant-garde, yaitu Antonin Artaud (Cantini, 2018).

Kehadiran kecenderungan teater postdramatik di Eropa-Amerika tidak bisa dilepaskan oleh keinginan untuk menggali sebuah kemungkinan bentuk teater yang lebih inovatif, di luar melulu bersentuhan dengan teks naskah drama. Spirit era postmodern menjadi momentum penting hadirnya bentukbentuk kesenian baru tersebut, khususnya teater.

Berkaitan dengan ini, Glenn D'Cruz (2018) menegaskan sebagai berikut.

Postmodernism provided a signifcant scholarly frame of reference for the work of artists such as robert Wilson, peter Sellars, richard Foreman, pina Bausch, robert Lepage and Laurie Anderson, and companies such as the Wooster Group, Mabou Mines, DV8 physical Theatre, Goat Island and Forced entertainment, among many others. The Sydney Front's earliest critics and commentators also used the vocabulary of postmodernism.

[Postmodernisme memberikan kerangka referensi ilmiah yang sangat penting untuk karya dari seniman-seniman seperti Robert Wilson, Peter Sellars, Richard Foreman, Pina Bausch, Robert Lepage, dan Laurie Anderson, serta perusahaan-perusahaan seperti Wooster Group, Mabou Mines, DV8 physical Theatre, Goat Island, dan Forced entertainment. Para kritikus dan komentator awal dari Sydney Front juga menggunakan kosakata postmodernisme.]

Sejalan dengan perspektif di atas, pada dekade 1960 dan 1970-an, kehidupan teater modern Indonesia berada dalam dua fase penting yang membentuk wilayah estetiknya, yaitu (1) teater dramatik modern yang berpijak pada spirit budaya lokal, dan (2) teater modern yang mengacu pada dramaturgi dramatik Barat. Spirit budaya lokal yang dimunculkan dalam teater dramatik era 1960an dan 1970-an, dituangkan dalam bentuk teks drama ataupun dalam bentuk pertunjukan teater. Misalnya, W.S. Rendra yang identik memberikan stimulan budaya Jawa di dalam karya teaternya, Putu Wijaya identik dengan kekuatan budaya lokal Bali, Arifin C. Noer memiliki kekuatan di dalam mengedepankan budaya lokal Cirebon, Nano Riantiarno yang lekat dengan budaya urban Jakarta, dan Wisran Hadi berkutat pada wilayah demitefikasi budaya lokal Minangkabau.

Hal di atas dikuatkan oleh pernyataan Kasim Ahmad (Tommy F Awuy, 1999), sebagai berikut.

Pementasan teater Arifin C Noer selalu terasa akrab dengan gaya teater rakyat daerah Cirebon. Wisran Hadi dalam menggarap teaternya terasa dekat dengan teater tradisional Minang, yaitu Randai. Ajim Ariyadi, dalam pementasan teaternya tidak melupakan gaya teater rakyat Mamanda. Studiklub Teater Bandung dalam pementasan "Lingkaran Kapur Putih" karya Bertold Brecht, menggunakan "dalang" sebagai pengganti "narator." Atau dalam teater tradisional kita temukan teater tutur yang diperagakan, seperti Topeng Dalang, teater rakyat Madura. 
Pementasan W.S Rendra, selalu diiringi tetabuhan yang diberi nama "Nyi Pilis", dan terasa dekat dengan teater rakyat di Yogyakarta.

Identitas teater Indonesia, menurut Kasim Ahmad adalah bentuk teater yang tumbuh dan berkembang, terutama di kota-kota besar sebagai hasil kreativitas bangsa Indonesia dalam persinggungan dengan kebudayan Barat lewat "teaternya". Hasil karyanya memperoleh pengaruh budaya lain, terutama secara teknis mengacu pada teater Barat dengan tetap mengadaptasinya pada esensi kebudayaan kita, dan berakar pada teater tradisional kita (1999:263). Tradisi penerjemahan sekaligus pengadaptasian teks dramatik (teks drama) Barat yang dikontekstualkan dengan kultur lokal pengkarya, dilakukan oleh Suyatna Anirun melalui Studiklub Teater Bandung (STB), seperti Pinangan, Orang Kasar (Anton P. Chekov), Mak Comblang (Nikolai Gogol), Romeo dan Juliet (William Shakespeare), dan lain-lain.

R.M. Soedarsono (2010) menyatakan sebagai berikut.

STB memang sangat produktif. Dramadrama penulis asing banyak yang diterjemahkan, antara lain karya-karya W.B Yeats, Anton Chekov, Nikolai Gogol, Robert Anderson, Tennese Williams, Shakespeare, Eugene Ionesco, F. Durenmatt, Goethe, David Storey, Bertold Brecht, dan Albert Camus. Di samping menampilkan karya-karya penulis drama asing, STB juga sering memanggungkan karya-karya putra Indonesia seperti, Saini KM, Utuy Tatang Sontani, Ajip Rosidim Kirdjomulyo, Kadarisman Achil, dan Motinggo Busje. Walaupun dalam pengamatan Jacob Sumardjo sebanyak 70 persen naskah-teks drama yang digarap oleh STB berasal dari Barat, tetapi di dalam pemanggungannya selalu lebih mengarah kepada adaptasi yang disesuaikan dengan budaya Indonesia. Misalnya saja naskah Romeo dan Julia (Romeo and Juliet), Romulus Agung
(Romulus the Great), dan Kuda Perang (War Horse) digarap dengan latar belakang kerajaan-kerajaan Indonesia lama.

Hal di atas juga dilakukan oleh W.S Rendra melalui proses pengadaptasian teks drama Oidipus Sang Raja, Antigone, dan Lysistrata dalam warna lokal budaya Jawa. Hal tersebut juga banyak dilakukan oleh para sutradara teater lainnya di Indonesia. Menguatnya dramaturgi dramatik Barat dalam teater modern Indonesia dipengaruhi oleh kecenderungan untuk menampilkan teks drama Barat melalui kultur asli yang mereka miliki. Mengikuti pola dan konvensi teater yang berkembang di Barat, seperti yang dikaji George R. Kernoddle dalam perspektif "well made play" (Yudiaryani, 2019). Teks drama yang memiliki jalinan dramatik yang sempurna, mampu memberikan kesan reflektif bagi pembaca ataupun penonton yang menyaksikannya. Wahyu Sihombing, bersama eksponen Akademi Teater Nasional Indonesia (ATNI) hadir sebagai pelopor yang konsisten di dalam mewujudkan dramaturgi teater Barat pada praktik teater di Indonesia.

Di antara dua fase di atas, yang dominan berkembang di Indonesia, terdapat satu kecenderungan baru dari bentuk teater yang tidak berpijak pada kecenderungan dramatika konvensional, seperti yang pernah dilakukan oleh W.S Rendra melalui kelompok Bengkel Teater, dan Putu Wijaya melalui kelompok Teater Mandiri. Perjalanan teater yang menitikberatkan pada wilayah tubuh tidak bisa dilepaskan oleh istilah fenomenal yang pernah hadir pada dekade 1960-an akhir setelah W.S Rendra pulang dari Amerika mementaskan teater berjudul Bip-Bop yang bertitik tolak pada tubuh. Istilah fenomenal ketika itu adalah teater mini kata. Istilah teater mini kata pada pementasan Bip-Bop karya W.S Rendra mendapat ulasan dari beberapa pengamat, antara lain Fuad Hasan yang berpendapat bahwa W.S. Rendra berupaya untuk mendramatisasikan penghayatan konflik pada manusia di abad moderen ini. 
Tanpa elaborasi intelektual yang sadar (yang memang tidak mutlak perlu), ia telah berhasil mengkonstantir suatu pola konflik yang khas dalam abad moderen ini, yaitu individuasi versus massifikasi, atau lebih mendesak lagi, humanisasi versus dehumanisasi (Birowo, 2014).

Selanjutnya, Arifin C. Noer, seperti yang juga dikutip Pandu Birowo, menegaskan tentang konsep dan bentuk pementasan BipBop karya W.S Rendra, yaitu upaya untuk mengembalikan teater pada kemurniannya dan membebaskannya dari tirani kesusasteraan dan amanat-amanat. Begitu juga Goenawan Muhammad mensejajarkan konsep mini kata dalam pementasan BipBop karya W.S Rendra dengan karya Eugène Ionèsco dengan menyebutkan bahwa karya tersebut berisi ungkapan suasana hati, tidak bertendensi ideologis, serta lebih merupakan impuls ketimbang program (Yudiaryani, 2015).

Adapun R.M. Soedarsono (2010) menyatakan bahwa di antara karya-karya yang disutradarai Rendra adalah Perjuangan Suku Naga, serta adaptasi drama-drama Yunani Klasik Oedipus Rex, Antigone, dan Lysistrata, Rendra mulai memperkenalkan gaya yang dijiwai oleh gaya Bertold Brecht yang agak absurd. Salah satu karya Rendra yang mengangkat isu-isu politik dan sosial tanah air ialah Bip-Bop. Lewat Bib-Bop yang dipanggungkan pertama di Cirebon ini, Renda mulai memperkenalkan konsep teaternya yang kita kenal dengan istilah 'mini kata'.

Goenawan Muhammad memberikan semacam kredo estetik terhadap eksperimen teater yang berpusat pada ekspresi gerak tubuh aktor di dalam karya Bib-Bop W.S Rendra dengan istilah Teater Mini Kata. Ekspresi estetik teater W.S Rendra ini juga direspons oleh Arifin C. Noer sebagai bentuk "Teater Primitif" dan Dami N. Toda menyebutnya sebagai "Teater Puisi."

Putu Wijaya bersama teater mandiri, muncul dengan warna berbeda pada pertunjukan teaternya. Ia cenderung meng- arah pada kekuatan visual (pencahayaan, kostum, properti), musik, multimedia yang antimainstream, dan menolak kemapanan bentuk teater realisme, dengan cara melakukan teror estetik kepada penonton. Hal ini, senada dengan apa yang disampaikan oleh Saini KM, dalam salah satu tulisannya sebagai berikut.

Putu Wijaya dengan vitalitasnya yang luar biasa dan gaya artaudian yang kuat memberondong penonton dengan citracitra (image) dan lambang-lambang (symbols) tentang proses dan dampak dehumanisasi terhadap masyarakat sebagai akibat perkembangan masyarakat yang terbuka terhadap pergaulan politik dan ekonomi dunia sejak era Orde Baru. Kalau pada Rendra, keprihatinan diungkapkan terutama melalui dialog (Perjuangan Suku Naga, Panembahan Reso), pada Arifin dengan citra-citra teatrikal yang distilisasi secara halus (Tengul, Interogasi), pada Putu Wijaya visi diungkapkan melalui citra dan lambang teatrikal yang sering mengerikan, dibarengi dialog yang menggebu, dan jeritan serta raungan (Sugiyati S.A; Mohamad Sunjaya; Suyatna Anirun, 1993).

Sementara itu, Benny Yohanes (2013) menjelaskan sebagai berikut.

Pertunjukan Putu Wijaya pada periode layar menjadi semacam transisi dari pergeseran penting dalam praktek tekstualisasi dalam teater modern di Indonesia. Pergeseran itu terlihat dalam cara membangun teks dalam teater; dari yang bersifat teks piramidal menjadi teks lateral. Tradisi "teks piramidal" adalah teks dramatik berbentuk teks lakon; seringkali disusun dengan struktur dramatik Aristotelian; menyajikan pentahapan konflik antar karakter; berbentuk alur cerita lengkap dan akhir lakon mengerucut pada sebuah klimaks dramatik sebagai konklusi akhir. Sedangkan "teks lateral" cenderung meniadakan pesan yang mengerucut. 
Fragmen-fragmen visual ditampilkan secara imprersif. Bentuk dramaturgi visual menggantikan peran plot dalam teater konvensional. Sudut pandang bagi setiap fragmen siuasi berubahubah, sehingga anonimitas tokoh jadi penting dari karakter yang eksplisit.

Berdasarkan penjelasan di atas, dapat disimpulkan bahwa kehadiran Putu Wijaya dalam praktik teater Indonesia bertolak pada kekuatan visual menjadi penting, sehingga berdampak dan berpengaruh pada kecenderungan bentuk teater yang dilakukan oleh seniman-seniman berikutnya. Kunci dari pertunjukan Putu Wijaya terletak pada usaha mencairkan keterlibatan emosional, seperti yang terdapat pada pertunjukan teater dramatik. Usaha mencairkan keterlibatan emosional ini digantikan dengan bentuk permainan; menjadi bayang-bayang dari realitas yang metaforik, bukan ingin menghadirkan realitas itu secara nyata.

Periode paruh kedua abad ke-20, beberapa grup teater yang melakukan penawaran eksplorasi dan elaborasi berpusat pada kekuatan visual artistik pertunjukan yang cenderung tidak dinaskahkan, seperti di Jakarta (Teater SAE, Teater Kubur), Bandung (Teater Payung Hitam), Surabaya (Teater Api), Medan (Teater Q), dan di beberapa tempat lainnya di Indonesia.

Berikut pendapat Benny Yohanes (Tommy F Awuy, 1999).

Teks tertulis yang menjadi titik berangkat ke arah perwujudan pertunjukan lebih banyak hanya berupa cuplikan, kepingan teks, atau adonan dari berbagai ekspresi teks yang sumber-sumber epistemiknya tidak saling berkaitan. Sifat adonan itu multicolour, menjadi semacam "rujak teks.

Periode ini menjadi representasi awal setelah kecenderungan konsep teater mini kata W.S Rendra dan konsep bertolak dari yang ada Putu Wijaya era 1970-an, menjadi tolak ukur lahirnya bentuk teater baru yang berpusat pada kekuatan visual, artistik bukan pada wilayah narasi teks drama konvensional. Boedi S Otong (Teater SAE), disebut Benny Yohanes sebagai salah satu eksponen utama teater "rujak teks".

Terkait dengan istilah "rujak teks", Benny Yohanes menjelaskan sebagai berikut.

Pentas-pentas teater yang diwujudkan sebagai "rujak teks" ini ditandai oleh semacam proklamasi bahwa pertunjukan bukan pemindahan naskah, juga bukan pementasan bahasa. Pertunjukan "rujak teks" tidak memaparkan cerita atau menggambarkan karakterkarakter secara bulat. Panggung juga diperlakukan bukan sebagai tempat untuk memilihara konsep keutuhan dan kebenaran berbahasa. Pertunjukan lebih diwujudkan sebagai spirit presentasi, energi fisik, kolase aksi, dan komposisi visual (Benny Yohanes, 2017).

Istilah di atas bertujuan untuk mengamati kecenderungan Teater SAE yang mengedepankan beragam penanda visual yang terdapat di atas panggung melalui tubuh aktor, narasi, properti, pencahayaan, kostum, bahkan mulitimedia. Praktik penyutradaraan Boedi S. Otong menggambarkan realitas dari kontaminasi benda-benda. Di dalam ruang kontaminasi ini, sejarah retak bahasa (langue) dan invensi subversif benda-benda yang ingin jadi bahasa (parole) saling menempur, atau saling bertukar posisi merebut dominasi untuk menyatakan ruang-ruang otonomnya sendiri (Benny Yohanes, 2017). Semenjak tahun 1984, Teater SAE bersama Boedi S. Otong melahirkan beberapa nomor pertunjukan, yaitu Teater Pengantar Ekstase Kematian Orang-Orang, Happening Channel $O 0$ (1986), Pertumbuhan di Atas Meja Makan (1991), Biografi Yanti Setelah 12 Menit (1992), dan Migrasi dari Ruang Tamu (1993).

Berdasarkan pemaparan tentang praktik teater postdramatic di Barat dan di Indonesia tersebut, secara bentuk tentu saja memiliki perbedaan yang mendasar secara estetik ataupun artistik. Benang merah yang paling mendasar terlihat pada produksi 
pengetahuan antara kecenderungan praktik teater yang tidak lagi berpusat pada teks drama dan konstruksi plot pertunjukan yang tidak mengacu pada plot Aristotelian. Praktik 'ketubuhan' yang dilakukan oleh Vsevelod Meyerhold, Antonin Artaud, dan Jerzy Grotowsky, menginspirasi W.S Rendra, Putu Wijaya, Boedi S. Otong, Dindon WS, Rachman Sabur, Yudi A. Tajudin, bahkan Yusril untuk melakukan kecenderungan yang persis sama di dalam memperlakukan tubuh dan benda-benda sebagai teks utama di dalam pertunjukan teaternya. Pada kenyataannya, masing-masing seniman teater di Indonesia tentu saja memiliki pembenaran bahwa proses kreatif yang dilakukannya adalah orisinil, tidak terpengaruh dengan praktikpraktik teater seniman besar sebelumnya. Akan tetapi, persinggungan secara wacana, jelas menjadi poin penting bahwa bentukbentuk teater dalam persepektif postmodern telah meruntuhkan konvensi teater modern yang berpijak pada teks drama (realisme, surealisme, dan absurd).

Banyak sekali apropriasi ketubuhan yang dikaitkan dengan negosiasi isoterik dalam berbagai local genius di Indonesia. Tradisi kreatif para empu seni di berbagai wilayah di Indonesia masih meninggalkan jejak- jejaknya dalam berbagai mitos, artifak, dan tradisi lisan yang sayangnya terus tergerus oleh perubahan biosphere dan cybersphere yang membuat tercerabutnya nilai-nilai etika tubuh yang membenturkan energi tubuh dengan energi bumi, dalam berbagai manifestasinya (Widaryanto, 2019).

\section{Pembahasan}

\section{Menimang Budaya Lokal sebagai Ranah Praktik Penciptaan Teater Postdramatik}

Membicarakan dramaturgi teater Indonesia, tentu saja tidak sesederhana seperti yang dibayangkan. Hal tersebut membutuhkan waktu panjang dan barangkali saja tidak akan pernah usai, mengingat segala elemen estetik dan artistik dalam setiap praktik penciptaan teater saling bergumul, kait berkelindan, baik itu dalam ranah eksplorasi, aspek dramaturgikal, maupun di dalam metode penciptaan yang dilakukan.

Perkembangan waktu, tentu saja mengubah perspektif dan pola dramaturgi di setiap praktik penciptaan teater di Indonesia. Hal itu mengubah bentuk dramaturgi yang dibangun dalam karya teater tersebut. Pertemuan teater dalam bentuk Drama Empat Kota tahun 1971 (Jakarta), Pekan Teater Empat Kota tahun 1976 (Jakarta), Pekan Teater Enam Kota tahun 1978 (Jakarta), Pertemuan Teater Indonesia tahun 1980 (Jakarta), Pertemuan Teater Indonesia tahun 1985 (Jakarta), Pertemuan Teater Indonesia tahun 1993 (Solo), dan Temu Teater Indonesia tahun 1997 (Pekanbaru), merupakan peristiwa penting di dalam melihat dramaturgi teater Indonesia era 1970-an sampai dengan tahun 1990-an akhir. Tentu saja hal itu dengan berbagai persoalan yang dialami para seniman teater saat itu, semisal keterbatasan infrastruktur, teknis pertunjukan, finansial, termasuk kurang berperannya pemerintah dalam menumbuhkembangkan aktivitas teater, dan mempertanyakan kembali identitas teater Indonesia itu seperti apa.

Pertemuan Teater Indonesia tahun 1980 yang dilaksanakan di Taman Ismail Marzuki (TIM) Jakarta, pada tanggal 28 Februari sampai dengan 7 Maret 1980, menjadi momen penting di dalam membaca kecenderungan estetik terhadap praktik penciptaan teater di kala itu. Para praktisi teater dari berbagai wilayah di Indonesia, seperti W.S. Rendra, Putu Wijaya, Wahyu Sihombing, Pramana Padmadamaya, Nano Riantiarno, Danarto, Ikranegara, Wisran Hadi, Aspar, dan A.A. Linde hadir berkontribusi dalam mempresentasikan kertas kerja penciptaan teaternya.

W.S. Rendra menyoroti tentang kebertahanan seniman teater dalam mencipta karya yang tidak tergantung dengan fasilitas pertunjukan yang ideal, tentang penonton, tentang keterbatasan kritik seni, termasuk juga tentang kerja keaktoran. Putu Wijaya 
menunjukkan kredo "bertolak dari yang ada" sebagai bentuk siasat dalam menyikapi segala keterbatasan pada praktik penciptaan teater yang dilakukannya. Salah satu kalimat pamungkasnya, "Kreativitas yang penulis percayai sebagai sesuatu yang tidak terbatas, tak ada pemasungan macam apapun yang benar-benar dapat memandulkan usaha mencipta-apalagi membunuhnya" (Wahyu Sihombing, Slamet Sukirnanto, 1980). Segala keterbatasan, justru menjadi tantangan bagi praktisi teater (sutradara) dalam mencipta karya teater yang estetik ataupun artistik.

"Kerja teater adalah kerja kooperatif dan kolektif. Hubungan yang akrab dan dinamik, selalu membuka kemungkinan untuk saling membuka diri, kebebasan bertanya, diskusi, saling menerima dan memberi, mempersoalkan aspek kreatif dan teknis pada pengadeganan gerakan atau ucapan" (Wahyu Sihombing, Slamet Sukirnanto, 1980). Begitu Wahyu Sihombing memberikan stimulan atas proses kreatif yang dijalaninya di Teater Lembaga (diasuh oleh Departemen Teater LPKJ), melalui sebuah studi penafsiran terhadap naskah drama Musuh Masyarakat karya Henrik Ibsen. Pramana Pmd menelisik tentang sinergisitas praktik penyutradaraan dengan aktor, termasuk dengan para penata. Masing-masing tim ini tentu saja berkontribusi dalam memperkuat spektakel pertunjukan secara estetik dan artistik.

Nano Riantiarno menunjukkan dramaturgi teater yang digarapnya bertolak pada spirit local, seperti Lenong, Ketoprak, Masres (semacam ketoprak di Cirebon), Wayang Orang, Wayang Kulit, Tarling, dan Cemeng. Ia memadukan berbagai bentuk kesenian tradisional Indonesia ke dalam bentuk penggarapan teater musikal yang modern. Istilah "Menuju Teater Tanpa Penonton" ala Danarto tentu saja bukan bermaksud untuk membuat jurang pemisah antara tontonan dan penonton, melainkan ingin memperlihatkan bahwa posisi penonton dengan tontonan itu adalah sama, melebur menjadi satu kesatuan pertunjukan teater yang holistik.
Dramaturgi teater Ikranegara, berpusat pada peleburan semua aspek dalam pertunjukan. Hal itu tidak melulu mengedepankan aktor sebagai poros utama pertunjukan, tetapi juga mengeksplorasi elemen lain, seperti elemen artistik, musik, dan lain-lain sehingga memiliki kedudukan yang sama di dalam proses, termasuk pada wilayah spektakel pertunjukan. Hal tersebut dilakukan sebagai bentuk penolakannya terhadap dramaturgi teater realisme yang ia pandang tidak relevan terhadap proses teater yang cenderung terlalu menghamba kepada aktor, sehingga memposisikan elemen pertunjukan lain sebagai subordinat. Hal ini terlihat di beberapa nomor pertunjukannya, seperti Topeng, Para Narator, Agung, Ssst!!!, dan Gusti.

"Teater bukan sekadar pembeberan ide, sekadar pergulatan sebuah tema, tetapi ia harus lebih dari itu. Panggung hendaknya menampilkan 'daya pikat' yang menyodorkan kekuatan merangsang perhatian, imajinasi, telinga, dan mata batin penontonnya," ucap Aspar Paturosi (1980: 132) untuk menutup rasa berdosanya terhadap pertunjukan teater yang pernah ia garap bersama temantemannya pada tahun 1962 berjudul Bulan Bujur Sangkar, naskah Iwan Simatupang. Semula penonton memadati gedung pertunjukan, tetapi setelah limabelas menit pertunjukan berlangsung, akhirnya penonton beringsut keluar dan hanya menyisakan puluhan penonton saja.

Kesenian randai di Minangkabau yang memuat unsur cerita, legaran, dendang (gurindam), tepuk galembong, merupakan bentuk dramaturgi yang kompleks. Akan tetapi, Wisran Hadi membuatnya lebih inovatif dengan cara menggabungkannya dengan metode penggarapan teater modern. Tentu saja, konvensi yang dibangun di dalam randai mengalami pergeseran bentuk dan makna karena menyesuaikan dengan kebutuhan tontonan. Untuk itu, Wisran Hadi mengedepan kekuatan bahasa (dialog) dan unsur rupa dalam wilayah artistik pertunjukan. "Melukis di atas Pang- 
gung", begitu Mbah Roejito menyebutnya. Begitu juga A.A Linde, membahas tentang catatan kerja penyutradaraannya yang berpijak pada dramaturgi lokal Minangkabau, yaitu (1) pantun atau gurindam yang didendangkan, dan (2) gerak yang berpijak pada kesenian randai, silat dan uluambek, termasuk juga unsur lain, seperti indang, basijobang, dan lain-lain.

Kata kunci yang dapat dipetik dari penjelasan mengenai kertas kerja teater yang dilakukan oleh masing-masing sutradara di atas adalah pentingnya untuk melihat dramaturgi budaya lokal sebagai identitas dan entitas kebudayan Indonesia yang dijadikan sebagai gagasan utama dalam praktik penciptaan teater, baik itu bertolak pada naskah drama maupun non naskah drama. Begitu juga, Pertemuan Teater 1985 dengan tema "Menggali Nilai Tradisional dalam Teater Modern" pada tanggal 5 sampai dengan 9 Maret 1985 di Taman Ismail Marzuki-Jakarta, semakin menegaskan bahwa penting kembali untuk menengok tradisi sebagai sebuah alternatif dalam praktik penciptaan teater. Tentu saja, masing-masing sutradara memiliki kebebasan kreatif di dalam menafsir hal tesebut, apakah tetap berbasis pada teks naskah drama atau tidak. Namun demikian, spiritnya adalah pentingnya menggali potensi kesenian tradisi sebagai identitas artistik (Istilah: Leon Agusta) di dalam penciptaan teater. Forum diskusi teater ini dihadiri oleh Tuti Indra Malaon, Leon Agusta, Asrul Sani, Chairul Harun, Saini KM, Aspar, Arifin C. Noer, Umar Kayam, Putu Wijaya, Sardono W. Kusumo, Mursal Esten, Hamid Jabbar, A. Kasim Achmad, Arswendo Atmowiloto, Roedjito, dan sebagainya.

Pada konteks ini, penulis melihat bahwa pelahiran bentuk-bentuk karya teater yang berpusat potensi budaya lokal yang ditransformasikan melalui aspek tubuh, kata, benda, musik, pencahayaan, sebagai teks utama memberikan daya gugah terhadap perkembangan teater Indonesia yang memiliki benang merah dengan era postmodern yang berkembang pesat di Eropa-Amerika era tahun 1970-an dengan berbagai istilah teater yang disebut oleh Elinor Fuch sebagai Total Theatre, alternative theatre, theatre of image, landscape theatre, neo avantgarde, dan semua yang terkait dengan 'post' seperti postnarrative, posthumanist, dan postmodern. Lehmann (Afrizal et al., 2019) menjelaskan sebagai berikut.

Research on the post theatre has clearly answered important needs for a comprehensive and accessible theory to articulate the relations between drama and the forms of theatre that is 'no longer dramatic' compared to its appearance in the 1970s. Hans-Thies Lehmann has systematized his reading of the new theatre form into several aspects which are actually different from dramatic theatre readings. The aspect can be seen from the sub-title written by Lehman in his book Panorama of Postdramatic Theatre, including text, space, time, body and media as an analysis category in reading new theatre forms/dramatic theatre.

[Penelitian tentang pasca teater dengan jelas menjawab kebutuhan penting akan teori yang komprehensif dan dapat diakses untuk mengartikulasikan hubungan antara drama dan bentukbentuk teater yang 'tidak lagi dramatis' dibandingkan dengan kemunculannya di tahun 1970-an. Hans-Thies Lehmann telah mensistematisasikan pembacaannya terhadap bentuk teater baru ke dalam beberapa aspek yang sebenarnya berbeda dengan pembacaan teater dramatik. Aspek tersebut terlihat dari sub judul yang ditulis oleh Lehman dalam bukunya Panorama of Postdramatic Theatre, termasuk teks, ruang, waktu, badan dan media sebagai kategori analisis dalam membaca bentuk teater baru/ teater dramatik].

Hal ini kemudian menjadi dasar lahirnya satu istilah baru yang spesifik dengan nama Teater Postdramatik. Istilah tersebut diteorisasi oleh Hans-Thies Lehmann melalui bukunya berjudul Postdramatic Theatre, diterbitkan 
pertama kali pada tahun 1999, sebagai bentuk spirit kehidupan teater di era postmodern. Kehadiran teks, ruang, waktu, tubuh, dan media menjadi prinsip utama di dalam menganalisis karya-karya teater tersebut.

\section{Teater Postdramatik Indonesia dengan Dramaturgi Budaya Lokal}

Kehidupan teater Indonesia, baik itu bertolak pada teks dramatik maupun dalam persepektif postdramatik semenjak era 1970an sampai hari ini, tidak bisa dilepaskan dengan eksplorasi terhadap potensi budaya lokal. Hal ini dapat diamati dalam konteks penulisan naskah drama, ataupun gaya pertunjukannya. Era postmodern yang tumbuh dan berkembang di Eropa-Amerika, apakah itu disadari atau tidak, telah mempengaruhi kecenderungan seniman teater kala itu untuk melahirkan karya berupa naskah drama ataupun pertunjukan yang tidak mainstream. Bukan pergulatan dialog antartokoh yang utama, melainkan konstruksi suasana/ peristiwa yang lebih penting. Tokoh tidak lagi menjadi subjek di dalam pertunjukan teater. Terkadang tokoh bisa saja menjadi objek yang berperan sebagai siapa dan apa saja. Hal ini dapat dilihat dalam karya W.S. Rendra, Putu Wijaya, Arifin C. Noer, Akhudiat, Aspar, termasuk juga Wisran Hadi di Sumatera Barat.

Tahun 1990-an merupakan era penting dalam melihat karya teater yang tidak melulu dipahami berada dalam "kepemimpinan kata" (mengutip istilah Afrizal Malna). Teater semula hanya dilihat sebagai reproduksi tokoh-tokoh arus Shakespearian dan Chekovian. Teater didominasi oleh kesusastraan (naskah drama), sehingga membiarkan tubuhnya terbelenggu oleh bahasa dialog antartokoh tersebut di atas panggung. Oleh karena itu, pada tahun 1990an lahir satu kecenderungan bentuk teater yang bertolak pada kesusastraan tubuh dan benda-benda sebagai teks utama dalam proses penciptaan teater.

Era Teater "Mini Kata" melalui Bip-Bop W.S. Rendra, dan "Teater Bodoh" ala Putu
Wijaya melalui karya Lho, Entah, Nol yang lebih mengedepankan aksi daripada relasi, jelas telah memberikan kontribusi besar terhadap praktik teater postdramatik era 1990-an melalui eksponen Ray Sahetapy (Studio Oncor), Boedi S. Otong (Teater SAE), Dindon WS (Teater Kubur), Rachman Sabur (Teater Payung Hitam), Asia Ramli Prapanca (Teater Kita Makassar), Joko Bibit Santosa (Teater Ruang), Harris Priadie Bah (Teater Kami), Yudi A. Tajudin (Teater Garasi), Luhur Kayungga (Teater API), Yusril Katil (komunitas seni Hitam-Putih), dan sebagainya. Masingmasing sutradara ini mengekplorasi idiomidiom tradisinya untuk dijadikan sebagai konsep penciptaan teater.

Proses FTJ dengan menggunakan naskah pemenang lomba terpaksa diubah, yakni dengan meniadakan keharusan mementaskan naskah pemenang lomba pada tahun 1987. Hal tersebut tentu mendatangkan keuntungan bagi sejumlah kelompok seniman yang menjunjung tinggi idealisme pementasan yang diyakininya. Kemunculan ini ditandai dengan pementasanpementasan eksperimen teater, seperti Teater SAE, Teater Kubur, Bandar Teater Jakarta, Teater Gelanggang Jakarta Timur, Teater Aquilla, dan masih banyak lainnya (Haerudin, 2021).

Penulis belum pernah melihat pertunjukan Boedi S. otong (Teater SAE) secara langsung, tetapi tahu dari buku, artikel di koran, dan internet, tentang beberapa nomor karya teater yang berpijak pada kata, tubuh, dan benda sebagai teks utama, seperti Konstruksi Keterasingan (1983), Teater Pengantar Ekstase Kematian Orang-Orang, Happening Channel 00 (1986), Pertumbuhan di Atas Meja Makan (1991), Biografi Yanti Setelah 12 Menit (1992), dan Migrasi dari Ruang Tamu (1993). Hampir secara keseluruhan, karya-karya Boedi S. otong menempatkan tubuh, kata, dan benda sebagai kendaraan praktik dalam mempersoalkan fenomena urban, dehumanisasi, keterasingan, di dalam karya teaternya. Tentu saja, Afrizal Malna sebagai dramaturgi sangat berkontribusi 
besar terhadap proses kreatif teater yang dilakukan Boedi S. otong. Termasuk juga karya Ray Sahetapi (Studio Oncor) dengan judul Gokil $=\mathrm{Kau}+\mathrm{Dia}-\mathrm{Aku}$, sebuah karya teater yang ditampilkan di dalam rumah dengan manusia yang dibaluti perban, sehingga terjadi pendistorsian terhadap tubuh sehari-hari.

Sandiwara Dol karya Dindon W.S. produksi Teater Kubur Jakarta, pernah penulis tonton di Taman Budaya Jambi pada tahun 1998. Pada saat itu penulis juga terlibat sebagai aktor dalam pertunjukan Menunggu, sutradara Yusril Katil produksi komunitas seni Hitam-Putih. Menurut penulis, hanya Yusril Katil saja ketika itu yang menjadikan tubuh, kata, dan benda sebagai teks utama teaternya. Ternyata, Teater Kubur juga memperlihatkan potensi yang luar biasa di benak penulis yang baru tamat SMA ketika itu. Hal ini, ternyata bersinergi dengan pemanfaatan kata, tubuh, dan benda dalam karya teater Rachman Sabur (Teater Payung Hitam), seperti Kaspar, Merah Bolong Putih Doblong Hitam, termasuk beberapa nomor lain yang pernah penulis tonton, seperti Ritual Bumi (2006), Perahu Noah (2007), Puisi Tubuh yang Runtuh (2009), Segera (2013), dan Post Haste (2016). Hampir secara keseluruhan, tema yang diusung oleh Rachman Sabur bertolak pada kritik sosial, ekologi, urban, diri, dan lain sebagainya. Tetapi, satu hal yang tidak bisa dipungkiri bahwa Rachman Sabur sebagai sutradara tetap meletakkan dramaturgi lokal di dalam karya-karyanya, baik itu gestur, properti, pola narasi, maupun nyanyian yang dihadirkan.

Sejatinya, proses penggarapan teater terjadi dengan adanya spirit kolaboratif antara dramaturg, sutradara, para penata artistik, termasuk juga penata musik di dalam satu produksi. Akan tetapi, beberapa sutradara teater juga melakukan kolaborasi dengan beberapa seniman dalam negeri ataupun luar negeri. Misalnya, Asia Ramli Prapanca sering melakukan itu, melibatkan Julie Janson (penulis teks), Sally Sussman dengan judul The Eye of Marege. Termasuk juga karya yang lain seperti Sawah yang Mengetuk Jendelaku, melibatkan Pak Ram sebagai sutradara, berkolaborasi dengan Ellin Krinsly Sydne (Australia) dan Arie Van Dujin (Belanda).

Seniman teater lain, misalnya Yudi A. Tajudin akhir tahun 2020 menghadirkan pertunjukan di ruang virtual dengan judul UrFear: Huhu \& Multitude of Peer Gynt, berkolaborasi dengan ahli IT untuk pembuatan situs web, aktor dan penari berasal dari Indonesia, Sri Lanka, dan Jepang. Di Sumatera Barat, Yusril Katil juga pernah melakukan hal yang sama, berkolaborasi dengan Rhoda Gauer, Restu Imansari Kusumaningrum dalam penggarapan teater berjudul Under The Volcano, yang ditampilkan dalam Olimpide Teater ke-6 di Beijing, Cina, tahun 2014. Tentu saja, masih banyak seniman teater lain yang melakukannya. Periode abad kedua puluh merupakan momen penting di dalam mencermati bentuk teater yang lebih mengedepankan aspek visual, dibandingkan dengan dialog-dialog, seperti halnya karya Robert Wilson hanya berisi ucapan-ucapan spontan tanpa ada naskah dalam pengertian tradisi oral (Yudiaryani, 2002; Yudiaryani, 2015). Tahun 2000, semasa penulis menjadi Ketua Hima di Jurusan Seni Teater STSI Padangpanjang (sekarang ISI Padangpanjang), pernah melihat pertunjukan dengan judul Caligula karya Albert Camus yang dibawakan oleh Teater API Surabaya di Taman Budaya Padang. Naskah drama yang begitu panjang, didekonstruksi habis sehingga hanya menyisakan dua orang aktor saja di atas panggung dengan menghadirkan kekuatan kata, tubuh, dan benda-benda. Akhirnya, karena tertarik dengan pertunjukan tersebut, penulis mengajak Mas Luhur dan tim untuk tampil di Padangpanjang. Hal ini menjadi perbandingan bagi teman-teman mahasiswa saat itu dalam melihat perkembangan dramaturgi teater yang terus bergerak maju dan dialektis.

Tentu saja, pergulatan dramaturgi teater Indonesia terus bergerak secara dialektis sampai saat ini, baik secara bentuk, maupun secara pewacanaan teater yang selalu tumbuh 
di bilik-bilik diskusi proses kreatif. Termasuk juga, pandemi Covid-19 yang berdampak kepada proses kreatif, strategi pertunjukan apakah tetap memilih pertunjukan secara langsung, atau mencoba beralih ke ranah virtual, termasuk bagaimana menyikapi kebertahanan sumber ekonomi seniman teater untuk terus berkarya, sekaligus juga menghasilkan. Polemik itu terus bergumul di beberapa kesempatan diskusi, webinar yang diselenggarakan oleh beberapa komunitas ataupun lembaga, seperti Yayasan Pelaku Teater Indonesia (YPTI), Pelaku Nasional Seni Teater Indoensia (Penastri), dan Suara Teater Nusantara (Suasana).

\section{Yusril Katil: Eksponen Teater Postdramatik di Sumatera Barat}

Pertama kali mengenal teater dan Yusril Katil pada tahun 1995, saat sekolah di SMA Plus INS Kayutanam. Saat itu juga mengetahui bahwa ada kelompok teater pelajar dengan nama Teater Plus INS Kayutanam. Terdapat dua karya yang sedang produksi saat itu, yakni (1) Interne, dan (2) Menunggu. Penulis belum terlibat sebagai aktor, hanya menjadi kru artistik. Tentu saja, penulis sering hadir di sesi latihan, termasuk juga mendatangi beberapa tempat, seperti rumah sakit jiwa, panti jompo, kantor media massa cetak, pasar, termasuk juga beberapa plaza di kota Padang. Penulis tidak tahu, apa maksud dan tujuan Yusril Katil membawa kami ke sana. Ternyata itu adalah semacam riset.

Masing-masing aktor, diminta untuk mencatat apa saja yang ia temukan di saat berada di lapangan. Tentu saja, catatan itu tidak bisa dilihat (akses) lagi hari ini karena lemahnya pengarsipan terhadap segala bentuk catatan-catatan yang berkaitan dengan proses saat itu. Adapun yang tersisa hanya ulasan di media massa dan beberapa foto pertunjukan. Bertolak dari catatancatatan tersebut, Yusril Katil meminta para aktor untuk melatih tubuh, mengeksplorasi benda-benda (properti) sampai pada tahap mencipta satu atau beberapa peristiwa. Di beberapa peristiwa tersebut baru diselipkan kata, beberapa kata, bahkan kalimat panjang yang dinilai relevan untuk diucapkan oleh aktor. Interne lahir sebagai bentuk karya teater yang memperlihatkan potret manusiamanusia yang sakit, tubuh-tubuh dan pikiran diamputasi oleh rezim kekuasaan. Sementara itu, Menunggu lahir sebagai bentuk karya teater yang menyoroti tentang rezim Orde Baru yang berwatak militeristik sehingga membungkam suara-suara kritis di masyarakat, demokrasi hanya jargon, koran, buku dan majalah yang tidak sejalan dengan alur kekuasaan pasti dibredel. Interne pernah ditampilkan di Padang (1996), Pekanbaru (1997), Kayutanam (1997), Jambi (1997), dan Bengkulu (1998). Adapun Menunggu pernah ditampilkan di Kayutanam (1997), Padang (1997), Pekanbaru (1997), Jambi (1998), dan Jakarta (2000).

Periode selanjutnya, penulis sering diajak oleh Yusril Katil sebagai aktor, stage manager, bahkan sebagai asisten sutradara pada proses teater di komunitas seni HitamPutih. Hampir secara keseluruhan, karyakaryanya bertolak pada kata, tubuh, dan benda sebagai teks utama penciptaan teaternya. Ada beberapa lakon Wisran Hadi, Zak Sorga, dan Iwan Simatupang, yang digarap, tetapi tetap saja didekonstruksi berdasarkan kecenderungan Yusril Katil yang tidak setia dalam mentrasformasi naskah drama apa adanya ke atas panggung. Pergulatan teks, tubuh, ruang, waktu, dan media sebagai bentuk cerminan teater postdramatik, tergambar dalam karya-karya teater Yusril Katil, seperti Kado, Pledoi, Pintu, Tangga, Pagar, Under The Volcano, Kamar Mandi Kita, Bangku Kayu dan Kamu yang Tubuh di Situ, dan Tubuh Padang (Theatre et al., 2007).

\section{Penutup}

Pergulatan teater Indonesia semenjak tahun 1970-an sampai dengan hari ini, pada dasarnya tetap bergerak secara dialektis, dengan pancarian bentuk-bentuk 
dramaturgi yang dinamis di berbagai wilayah di Indonesia. Pergulatan ini dapat dilihat dari penulisan naskah, penggarapan teater yang bertolak pada teks dramatik, termasuk penggarapan teater yang justru keluar dari kecenderungan teks dramatik tersebut. Tahun 1990-an, dipandang sebagai puncak lahirnya seniman teater bersama karya-karyanya yang menjadikan kata, tubuh, dan benda (material artistik) sebagai teks utama di dalam penggarapan teater. Begitu banyak istilah yang disematkan terhadap kecenderungan praktik teater ini. Ada yang menyebut teater eksperimental, teater kontemporer, teater total, teater tubuh, teater tari, dan sebagainya. Sementara itu, di tahun 1999 muncul istilah baru untuk memahami teater ini, yaitu teater postdramatik yang dicetuskan oleh HansThies Lehmann. Saaduddin menjelaskan bahwa bentuk penyajian seni pertunjukan, apa lagi pertunjukan seni teater, dipengaruhi oleh perkembangan teknologi dan selera masyarakat penonton yang senantiasa berubah. Perubahan tersebut dapat dirasakan ketika kita menonton sebuah pertunjukan (Saaduddin dan Novalinda, 2017). Kehadiran teater yang berbasis pada tubuh, melalui gerak-gerak terstruktur ataupun improvisasi, menghadirkan motif-motif tersendiri di dalam mencipta peristiwa. Afrizal mengutip Vera \& Crossan, menjelaskan bahwa konsep teater improvisasi sering dikaitkan dengan sebuah kerja bersama aktor untuk menerima saran dari penonton dan menciptakan sebuah pristiwa dan adegan di atas panggung tanpa naskah apapun (H et al., 2020).

Kehadiran teater mini kata W.S. Rendra, dan teater visual Putu Wijaya, jelas memberi pengaruh terhadap perkembangan teater Indonesia, baik dalam konteks penulisan naskah drama maupun dalam konteks penciptaan teater yang dilakukan. Hadirnya, tokoh-tokoh teater yang bersinergi dengan kecenderungan teater postdramatik, seperti Boedi S. Otong, Dindon W.S., Rachman Sabur, Asia Ramli Prapanca, Yudi A. Tajudin, Yusril Katil, dan sebagainya, tentu saja telah memberi warna terhadap potret dramaturgi teater Indonesia hari ini.

\section{Kepustakaan}

Afrizal, H., Sarwanto, Soetarno, \& Murtana, I. N. (2019). The Aesthetic Forms of Postdramatic Theatre Work "Under the Volcano" Directed By Yusril. American Journal of Humanities and Social Sciences Research (AJHSSR), 3(5), 22-30.

Benny Yohanes. (2013). Teater Piktografik: Migrasi Estetik Putu Wijaya dan Metabahasa Layar (N. N. S.S (Ed.); Pertama). Dewan Kesenian Jakarta.

Benny Yohanes. (2017). Metode Kritik Teater Teori, Konsep dan Aplikasi (I. S. Yuga (Ed.); Pertama). Kalabuku, Yogyakarta.

Birowo, P. (2014). Teater 'Tanpa-Kata' dan 'Minim-Kata' di Kota Padang Dekade 90An dalam Tinjauan Sosiologi Seni. Ekpresi Seni. Jurnal Ilmu Pengetahuan Dan Karya Seni, 16(2), 314-335.

Cantini, C. (2018). Wacana Pos-Dramatik dalam Teater Pooh-Pooh Somatic: on Crowd of Biographies Karya Kalanari Theater Movement Yogyakarta. TAMUMATRA: Jurnal Seni Pertunjukkan, 1(1).

D'Cruz, G. (2018). Teaching Postdramatic Theatre: Anxieties, Aporias and Disclosures (G. D'Cruz (Ed.); Pertama). School of Communication \& Creative Art Deakin University Burwood, VIC, Australia ISBN. Dra. Yudiaryani, M. (2002). Panggung Teater Dunia (Lephen Purwaharja (Ed.); Pertama). Pustaka Gondho Suli.

H, A., YUSRIL, Y., \& SUSANDRO, S. (2020). Ota Lapau sebagai Alternatif Ide Penciptaan Teater Kontemporer Minangkabau. Ekspresi Seni: Jurnal Ilmu Pengetahuan dan Karya Seni, 22(2), 93-112.

Haerudin, D. (2021). Pengelolaan Pertunjukan Teater di Jakarta tahun 1972 hingga tahun 2017. Dance and Theatre Review, 4(1), 36-43. https://doi.org/10.24821/dtr. v4i1.4396

Prof. Dr. R. M. Soedarsono. (2010). Seni 
Pertunjukan Indonesia di Era Globalisasi (Ketiga). Gadjah Mada University Press.

Saaduddin, S., \& Novalinda, S. (2017). Pertunjukan Teater Eksperimental Huhh Hahh Hihh: Sebuah Kolaborasi Teater Tari. Ekspresi Seni : Jurnal Ilmu Pengetahuan Dan Karya Seni, 19(1), 39-57. https://doi. org/10.26887/EKSE.V19I1.128

Sugiyati S.A; Mohamad Sunjaya; Suyatna Anirun. (1993). Teater Untuk Dilakoni: Kumpulan Tulisan tentang Teater (S. S. A. M. S. S. Anirun (Ed.); Pertama). Studiklub Teater Bandung bersama Jeihan, bekerjasama dengan Penerbit CV. Geger Sunten.

Theatre, P., Lehmann, H., Jürs-munby, K., \& Varney, D. (2007). Postdramatic Theatre, 3(May).

Tommy F Awuy. (1999). Teater Indonesia:
Konsep, Sejarah, Problema (T. F. Awuy (Ed.); Pertama). Dewan Kesenian Jakarta. Wahyu Sihombing, Slamet Sukirnanto, I. (1980). Pertemuan teater 80 (I. Wahyu Sihombing, Slamet Sukirnanto (Ed.); Pertama). Dewan Kesenian Jakarta.

Widaryanto, F. X. (2019). Menyoal Ketubuhan dan Nilai Performatifnya. Dance and Theatre Review, 2(2), 53-63. https://doi. org/10.24821/dtr.v2i2.3309

Yudiaryani. (2015). WS Rendra dan Teater Minikata (Aprina Tri Retnaningrum (Ed.); 1st ed.). Galang Pustaka. http://digilib.isi. ac.id/1694

Yudiaryani. (2019). Melacak Jejak Pertunjukan Teater. Sejarah, Gagagsan, dan Produksinya (W. Nurcahyono (Ed.); 1st ed.). Badan Penerbit Institut Seni Indonesia Yogyakarta. http://digilib.isi. ac.id/id/eprint/7186 